1. Kryminal'ne pravo Ukrayiny: Zahal'na chastyna [Criminal Law of Ukraine: General part]: pidruch. / V. I. Borysov, V. Ya. Tatsiy, V. I. Tyutyuhin ta in. ; za red. V. Ya. Tatsiya, V. I. Borysova, V. I. Tyutyuhina ; 5-e vyd., pererob. i dop. Kharkiv : Pravo, 2015. 528 s. [in Ukr.]

2. Mitrofanov, I. I. (2017) Aktual'ni problemy rehulyuvannya vidpovidal'nosti u kryminal'nomu pravi [Actual problems of regulation of liability in criminal law]: monohraf. Odesa : Feniks, $450 \mathrm{~s}$. [in Ukr.]

3. Naukovo-praktychnyy komentar do Kryminal'noho kodeksu Ukrayiny [Scientific and practical commentary on the Criminal Code of Ukraine] ; za red. M. I. Mel'nyka, M.I. Khavronyuka. 10-e vyd., pererob. i dop. Kyyiv: DAKOR, 2018. 1368 s. [in Ukr.]

4. Panchenko, O. V. (2018) Kryminal'ne provadzhennya shchodo yurydychnoyi osoby [Criminal proceedings against a legal entity]: dys. ... kand. yuryd. nauk : 12.00.09 / Nats. yuryd. un-t im. Yaroslava Mudroho. Kharkiv, 203 s. [in Ukr.]

5. Provtorov, O. P. (2019) Zakhody kryminal'no-pravovoho kharakteru shchodo yurydychnykh osib yak instytut kryminal'noho prava Ukrayiny [Measures of Criminal Law Regarding Legal Entities as an Institute of Criminal Law of Ukraine]: dys. ... kand. yuryd. nauk : 12.00 .08 / In-t derzhavy i prava im. V. M. Korets'koho NAN Ukrayiny. Kyyiv, 20 s. [in Ukr.]

6. Yashchenko, A. M. (2019) Prymusovi zakhody kryminal'noho kharakteru shchodo yurydychnykh osib: prychyny i chynnyky zaprovadzhennya ta efektyvnist' zastosuvannya [Coercive measures of a criminal nature against legal entities: causes and factors of implementation and effectiveness of application]. Efektyvnist' kryminal'noho prava: doktrynal'ni, zakonodavchi ta pravookhoronni problemy: Mizhnar. nauk.-prakt. kruhlyy stil (m. Kharkiv, 17 travnya 2019 r.). Kharkiv : Vydavnytstvo «Konstanta», s. 243-247. [in Ukr.]

7. Yashchenko, A. M. (2017) Zvil'nennya yurydychnoyi osoby vid zastosuvannya kryminal'nopravovykh zakhodiv iz zakinchennyam strokiv davnosti: teoretyko-prykladnyy aspect [Exemption of a Legal Entity from the Application of Criminal Law Measures with Expiry of Limitation Periods]. Forum prava № 4. S. 300-308. URL : file: /// C: / Users / Admin / Downloads / ojWZb3Fe_xA8gVEANfWbADMRcOf3JZs\% 20 (1).pdf. [in Ukr.]

8. Yashchenko, A. M. (2016) Obstavyny, shcho vyklyuchayut' mozhlyvist' zastosuvannya do yurydychnykh osib zakhodiv kryminal'noho kharakteru [Circumstances that exclude the possibility of applying to the legal entities measures of a criminal nature]. Pidpryyemnytstvo, hospodarstvo i pravo. № 12 . s. 227-232. [in Ukr.]

\title{
Summary
}

In accordance with the analysis of the legal provisions of the section XIV-1 of the Criminal Code of Ukraine, as well as doctrinal definitions about content, grounds and conditions of application of measures of criminal nature in relation to legal entities, the preconditions, grounds and application of both forcible and unreasonable measures for further criminal proceedings against legal entities are defined.

Keywords: legal entity, prerequisite, basis, condition, application, measures of criminal law nature.

UDC 343.985

DOI: $10.31733 / 2078-3566-2019-5-237-242$

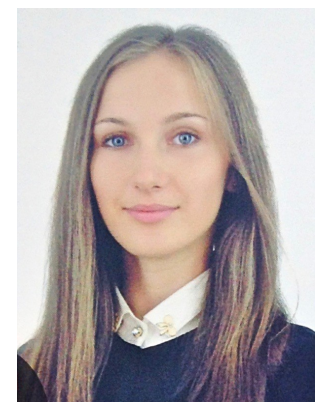

\author{
Anastasia SENKO $^{\complement}$ \\ Graduate student \\ (Dnipropetrovsk State University \\ of Internal Affairs)
}

\section{CRIMINAL PROVISION OF AN EXAMINATION DURING THE INVESTIGATION OF CITIZEN'S LUGGAGE THEFT COMMITED AT THE AIRPORT}

Анастасія Сенько. КРИМІНАЛІСТИЧНЕ ЗАБЕЗПЕЧЕННЯ ПРОВЕДЕННЯ ОГЛЯДУ ПІД ЧАС РОЗСЛІДУВАННЯ КРАДІЖОК БАГАЖУ ГРОМАДЯН, УЧИНЕНИХ В АЕРОПОРТУ. Наукова стаття присвячена висвітленню деяких аспектів проблемних питань розслідування крадіжок багажу громадян, учинених в аеропорту. Виокремлено наукові підходи до визначення поняття та структури криміналістичної характеристики кримінального правопорушення. Наголошено на значенні даної наукової категорії. Розглядаються особливості криміналістичного забезпечення проведення огляду для більш швидкого розслідування досліджуваної категорії кримінальних правопорушень. Автор зазначає, що огляд $є$ однією 3 найбільш розповсюджених слідчих (розшукових) дій при розслідуванні крадіжок багажу пасажирів в аеропортах.

\footnotetext{
(C) Senko A., 2019

k_ksmp@dduvs.in.ua
} 
Наголошено, що огляд належить до числа початкових, неповторних та незамінних слідчих (розшукових) дій. Правоохоронна практика свідчить, що дану слідчу (розшукову) дію не можна замінити іншими слідчими (розшуковими) діями, зокрема, допитами осіб, які є очевидцями злочинної події, оскільки жоден свідок не в змозі дати у своїх показаннях необхідного обсягу інформації, яку може виявити слідчий безпосередньо під час проведення огляду місця події, застосовуючи засоби криміналістичної техніки та допомогу спеціалістів. Під час огляду місця події оглядають усі об'єкти, які можуть мати відношення до злочину, залежно від конкретної слідчої ситуації, за внутрішнім переконанням слідчого. Тому інформативність слідчого огляду набагато вища, ніж, наприклад, одночасних обшуків чи слідчого експерименту за участю працівників аеропорту.

На перший план виходить обов'язкове виявлення та вилучення зазначеної інформації. Адже сліди вчинення суспільно-небезпечного діяння в місцях значного скупчення людей можуть бути досить швидко втрачені.

До огляду місця події вважаємо залучати наступні категорії осіб: працівники підрозділів кримінальної поліції (для охорони місця події, спостереження за поведінкою окремих осіб, обстеження прилеглої території, опитування очевидців, проведення оперативно-розшукових заходів); працівник НДЕКЦ; потерпілі; працівники патрульної поліції.

Співробітники правоохоронних органів, які розслідують крадіжки багажу громадян, учинених в аеропорту, повинні широко застосувати увесь арсенал загальних та спеціальних методів криміналістики, особливо техніко-криміналістичних засобів й методів роботи зі слідами та іншими речовими об'єктами, що дозволить ефективно та якісно проводити дану слідчу (розшукову) дію.

Значення огляду під час проведення досудового розслідування надзвичайно велике. Вказана слідча (розшукова) дія дозволяє слідчому безпосередньо сприймати місце події, об'єкти з метою виявлення слідів злочинної діяльності та з'ясування обставин події, що мають значення для кримінального провадження, скласти уявлення про механізм злочину та особу злочинця (працівника аеропорту), висунути слідчі версії та правильно визначити напрямки подальшого розслідування. Від своєчасності та якості проведення слідчих оглядів у багатьох випадках залежить успіх в розкритті, розслідуванні та профілактиці злочинів зазначеної категорії.

Ключові слова: крадіжки, організачія, тактика, слідчі (розщукові) дї, огляд, криміналістичне забезпечення.

Problem statement. In most cases, committing criminal offenses against property is characterized by sufficient evidence. The conduct of the thefts of luggage by citizens at the airport is also characterized by the existence of an appropriate trace pattern. Therefore, the mandatory identification and deletion of this information is a priority. After all, the traces of committing socially dangerous acts in places of large crowds can be lost fairly quickly. Among the investigative (search) actions of the initial stage of the investigation, different types of surveys are important. Therefore, providing appropriate guidance on their preparation and implementation is clearly necessary for law enforcement practical units.

Analysis of publications that started solving this problem. Scientists such as Yu.P. Alenin, V.P. Bakhin, V.D. Bernaz, R.S. Belkin, V.K. Veselsky, A.F. Volobuev, V.A. Zuravel, A.V. Ishchenko, O.N. Kolesnichenko, V.V. Lysenko, V.K. Lisichenko, I.M. Luzgin, V.G. Lukashevich, E.D. Lukyanchikov, Y. Y. Orlov, M.A. Pogoretsky, M.V. Saltevsky, R.L. Stepaniuk, L.D. Udalova, K.O. Chaplynskyi, Y.M. Chornous, V.Yu. Shepitko, M.P. Yablokov and others. However, the features of forensic screening during the investigation of the baggage of civilians committed at the airport have not been fully investigated, taking into account the current CPC of Ukraine and current law enforcement needs.

The article's objective is to investigate the forensic provision of an overview when investigating the thefts of baggage of citizens committed at an airport.

Basic content. According to some scientists, the beginning of the investigation is often characterized by a large amount of organizational, technical and tactical work of the investigator, who, first of all, "must properly navigate the available information, evaluate it correctly, make a decision and implement it in accordance with the objectives of criminal justice [1, $\mathrm{p}$. 19]. The conducted investigation of materials of criminal proceedings on the fact of theft of luggage of citizens at the airport, it was found out that at the initial stage such investigative (search) actions as inspection of the place of occurrence (73\%) are most often carried out; review of things and documents (51\%); interrogation of the victim $(100 \%)$ and witnesses $(84 \%)$; simultaneous interrogations of two or more interrogated persons $(27 \%)$, etc.

We support the position of forensic scientists, who say that at the initial stage of the investigation, law enforcement officials have the following tasks: 1) to find out the initial information about the theft and its verification, to nominate the initial investigative versions in the proceedings, to establish the facts to be investigated in the criminal proceedings; 2) detecting, securing and preserving the traces of crime; 3) identification of victims and witnesses; 4) identification of 
the suspect; 5) identification of circumstances of a criminal event, deepening and clarification of versions, drawing up an investigation plan; 6) search of the suspect and his detention, ensuring compensation for material damage [2, p. 393]. Outlined investigative (search) actions are conducted to solve certain tasks. Among them is the overview of the scene. Speaking about the essence and definition of its concept, it should be noted that a certain procedural action was formulated as a study of a particular area or its separate area, premises or building in which the crime was prepared, where it was committed or where the criminal consequences occurred or its traces can be stored, and may also have place review of individual objects, documents, corpse [3, p. 528].In turn, V. Y. Shepitko notes that the review is an investigative (search) action, which consists in the direct perception of the object in order to identify traces and other material evidence, to clarify the circumstances of the event, as well as the circumstances that have value in the case [4, p. 217]. And other criminologists claim that it consists in the direct perception, investigation and fixation by the investigator or investigator of the situation of the scene, as well as in the identification, fixation, seizure of traces and material evidence for establishing within the limits of the nature and circumstances of the event and the perpetrators [5, p. 253].In this context, it is necessary to agree with K.O. Chaplynskyi opinion that a minimum period of time should pass between the receipt of initial information about the crime and the beginning of the investigative examination [6, p. 16]. And already, A. Vasilyev has provided such definition - it is an investigative action, consisting in the direct perception, investigation and fixation by the investigator of the situation of the scene, as well as in the detection, fixation, removal of traces and physical evidence for establishing within the possible limits of character and circumstances of the event and perpetrators [7, p. 253].It should be noted that the purpose of the review is to identify on-the-spot evidence and other forensically relevant information about a criminal event that will facilitate faster understanding of the forensic characteristics of the committed act, to put forward investigative versions and identify the main areas of investigation, to ensure the possibility of "hot" investigations criminal, stolen property, termination of further criminal activity, etc. [5, p. 147]. That is, based on the purpose of the review and formulated most of its definitions. For example, I.N. Yakimov pointed out that due to this procedural action the truth was established in the investigation of a criminal case $[8, \mathrm{p} .101]$.

It should be noted that we share the position of E.P. Ishchenko, who defined the review as an immediate investigative action consisting in the direct perception, investigation and fixation by the investigator of the situation of the place, its traces and objects, their relationships and characteristic features of to find out the substance of the incident, the mechanism of the crime and other circumstances that are relevant for the proper resolution of the criminal case by the court $[9$, p. 206]. I.V. Soroka identified the following as one of the main tasks of the theft inspection:1) reproduction by the investigator of the picture of the event for the purpose of promoting the versions;2) identification and removal of traces of crime, tools and other objects that may be material evidence or relevant to the case;3) study and full display in the protocol of the review of the scene of the whole situation;4) identification of the immediate causes and conditions that facilitated (impeded) the commission of theft by minors [10, p. 90]. As E.P. Ishchenko notes, the review of the scene has two stages. The first includes investigator's actions prior to departure to the scene, and the second includes preparatory actions taken upon arrival. In the first stage, the investigator takes care of information-tactical and logistical support at the scene. He does his best to get the most complete information on what exactly and where the conditions are, what the conditions are for the review. At the same time it controls whether all urgent measures have been taken: to eliminate the harmful consequences of the event, to provide medical assistance to the victim, to the protection of the scene at the exit, which guarantees the trace of the offender, etc. [9, p. 209].Thus, V.V. Stepanov in the preparatory stage of the review allocates the following organizational and preparatory measures:- establishment of boundaries of the scene, in the process of which the nature of the actions is revealed;- taking into account the nature of the terrain and other factors, determine the order of spatial coverage of the event and movement of the survey participants;- solves the issue of organizing the work of the review participants, the distribution of their responsibilities;- Carrying out measures aimed at preserving the tracks at the scene;- solving the question of the use of technical means, which should be used at the scene [11, p. 90-91].Immediate departure to the place of theft, the optimal choice of tactical methods of examination allows the investigator to identify the offender at the initial stage of the investigation, to collect the initial data on the stolen property and on the basis of evidential and orienting information to form a verbal portrait of the alleged offender and to take measures to establish him. In his turn, E.I. Makarenko 
emphasized that even a slight delay or inappropriate organization of initial investigative (search) actions and search activities can lead to a reduction of information that may be a crime. Thus, the analysis of investigative practice in cases of apartment thefts shows that quite often there are also untimely departure to the place of theft, and the formal holding of the mentioned measures, and the local (within one administrative district) nature of search work on the identification of suspects of theft [12, p. 37].

I.V. Soroka's interesting position is that some of the criminals (about 3\%) return to the scene for the purpose of destroying traces or objects left behind, observing the actions of the investigator and finding out what information they possess, so and to continue their criminal activities. This is relevant not only for adult offenders, but also for minors who should not be underestimated. This is especially true when the minor is involved in the theft in conjunction with adult participants. In this case, the juveniles return to the scene, hoping that law enforcement agencies will not pay attention to them. This should also be taken into account not only by the investigator but also by the patrol officers who, upon arriving at the scene, may be the first to watch them from a certain distance from minors. The video capture with the help of a police officer's camera luggage, which may be caught by the juvenile offenders encountered on the patrol route by the police [13, p. 445]. In the context of the subject matter of our study, this claim may also be true, as airport thefts operate cyclically, returning to the crime scene again and again.

Among the preparatory actions for the inspection of the scene, we consider the most successful number of them: to obtain comprehensive information about the circumstances of the criminal offense; ensure the security of the scene (for example, by patrolling police forces not far from the crime scene, or the administration of the institution, etc.) and detain persons who are witnesses to the crime until the investigation team arrives; determine what measures have been taken to remedy the consequences of the criminal offense; arrange medical assistance for victims or persons who have committed an offense; determine the composition of the investigative-task force (if necessary, involve the necessary specialists); to ensure in advance that there are witnesses, if there is reason to believe that it will be difficult or impossible to attract them at the scene; to prepare the necessary scientific and technical means to ensure access to the site of the incident and to conduct the examination (forensic means, transport, communication, etc.); to decide on the use of a service dog; ensure the participation of the necessary participants in the conduct of this investigative (search) action [14, p. 217-218].Among the preparatory activities, in our opinion, the most important is to determine the circle of participants in the review of the scene. In particular, in order to conduct a review of the scene, $\mathrm{V}$. D.Polivanyuk believes, depending on the specific investigative situation, that the following persons should be part of the FGN:- Compulsory participants - Investigator specializing in the investigation of criminal offenses of a particular category (the head of the IOG) operational staff;- Optional participants - forensic inspector, who knows the features of dealing with traces of crimes in this category; the inspector of the security or security service of the object under review [15, p. 245].Other scientists claim that the following categories of persons are obliged to join the IOG:- obligatory participants: investigator or other authorized person (head of the IOG), employees of criminal police units (to protect the scene, to monitor the behavior of individuals, to inspect the surrounding area, to interview witnesses, to conduct search operations), understood;- Optional participants: forensic inspector who works to identify and collect traces left at the scene; an employee of the FRCC or the Forensic Research Institute, upon request, to identify and remove individual traces of a criminal offense, if necessary; the inspector of the security or security service of the object under review [16, p. 55]. And, for example, B. Yu. Bystritsky thinks that the examination, at the discretion of the investigator, may involve victims, witnesses and detained minors. The victim's involvement in the examination is conditioned by the circumstances of the theft. Victims can determine which items have been moved. It is advisable to focus on these objects to find the traces of the hands of criminals. In addition, it is found out which items have disappeared, their characteristics, the available documents. As a result, the speed of obtaining guidance information is significantly increased, which ensures the speed of detection and investigation of theft. These individuals can be helpful in identifying the boundaries of the scene, identifying individual traces and objects, or the signs of their destruction. They may also draw the investigator's attention to certain traces and objects, their features and features, which they consider important for criminal proceedings [17, p. 169].

Considering the investigation of materials of criminal proceedings on the facts of theft of citizens' luggage at airports, it is obligatory to involve the following categories of persons in 
the inspection of the scene:- employees of criminal police units (to protect the scene, monitor the behavior of individuals, survey the surrounding area, interrogate eyewitnesses, conduct search operations);- employee of FRECC;- the victims;- patrol officers.

Conclusion. To summarize, the review is one of the most common investigative (investigative) actions in investigating theft of passenger luggage at airports. The obligatory identification and deletion of the specified information comes to the fore. After all, the traces of committing socially dangerous acts in places of large crowds can be quickly lost. To review the scene consider the following categories of persons: criminal police officers (to protect the scene, monitor the behavior of individuals, survey adjacent territories, surveys eyewitnesses, conducting search operations); FRECC employee; the victims; patrol officers. A certain set of tactical techniques must be used to carry out the review effectively. This aspect will guide our further research.

\section{References:}

1. Гавло В. К. Некоторые методологические проблемы информационно-познавательной деятельности на первоначальном этапе расследования преступлений. Актуальные проблемы следственной деятельности / Отв. ред. И.Ф. Герасимов, Л.Я. Драпкин. Свердловск: Изд-во Свердл. юрид. ни-та, 1990, с. 17-21.

2. Белкин Р. С. Курс криминалистики: в 3-х т. М. : Норма, 1997. Т. 3, 393 с.

3. Следственные действия (процессуальная характеристика, тактические и психологические особенности) : учеб. пособие для вузов МВД СССР. Волгоград : ВСШ МВД CCCP, 1984. $155 \mathrm{c}$.

4. Криміналістика: Підруч. / Кол. авт.; за ред. В. Ю. Шепітька. Київ: Юрінком Інтер, 2001, $682 \mathrm{c}$.

5. Криминалистика : Учебник / Под ред. А. Н. Васильева. М. : Изд-во МГУ, 1980. 366 с.

6. Чаплинський К. О. Тактика проведення окремих слідчих дій: Монограф. Дніпропетровськ: Дніпроп. держ. ун-т внутр. справ, 2006., 308 с.

7. Гаврилин Ю. В., Головин А. Ю., Тишутина И. В. Криминалистика в понятиях и терминах: Учеб. пособие / Под ред. А. Ю. Головина. М.: Книжный мир, 2006, 384 с.

8. Якимов И. Н. Криминалистика : руководство по уголовной технике и тактике. М. : НКВД РСФСР, 1925. $430 \mathrm{c}$.

9. Ищенко Е. П. Криминалистика: Курс лекций. М. : Юридическая фирма «КОНТРАКТ»; АCТ-МОСКВА, 2007. 416 c.

10. Сорока І.В. Розслідування крадіжок майна громадян, вчинених неповнолітніми : дис. ... кандидата. юрид. наук : 12.00.09 / Дніпроп. держ. ун. внутр. справ, Дніпро. 2017. 256 с

11. Степанов В. В. Современные проблемы осмотра места происшествия. Сборник материалов Международной научно-практической конференции «Влияние идей И. Н. Якимова на развитие современной криминалистики», посвященной 130-летию со дня рождения И. Н. Якимова. М., 2014. С. 86-91.

12. Макаренко Є.I. Крадіжки 3 квартир: мистецтво розслідування: Монограф. Дніпропетровськ: Дніпроп. держ. ун-т внутр. справ, 2009, 150 с.

13. Сорока І. В. Особливості проведення слідчого огляду за фактами вчинених неповнолітніми крадіжок майна громадян. Науковий вісник Дніпропетровського державного університету внутрішніх справ. 2013. № 4. С. 444-449.

14. Криміналістика : підруч. для студ. вищ. навч. закл. / К. О. Чаплинський, О. В. Лускатов, I. В. Пиріг, В. М. Плетенець, Ю. А. Чаплинська. Дніпро : Дніпроп. держ. ун-т внутр. справ; Ліра ЛТД, 2017. 419 c.

15. Поливанюк В. Д. Тактичні особливості проведення огляду місця події при розслідуванні злочинів, вчинених у банківській системі України 3 використанням сучасних інформаційних технологій. Вісник Запорізького національного університету. № 1. 2011. С. 243248.

16. Антонюк Е.В. Особенности проведения отдельных следственных (розыскных) действий при расследовании хулиганства, предусмотреного ч. 4 ст. 296 УК Украины. Международный научно-практический журнал «Право и Закон». 2016. № 3. С. 53-58.

17. Бистрицький Б.Ю. Тактика огляду місця події під час розслідування грабежів, учинених неповнолітніми. Право і суспільство, 2015, № 4, с. 166-170.

Received to editorial office 11.12.2019

1. Gavlo, V. K. (1990) Nekotoryye metodologicheskiye problemy informatsionno-poznavatel'noy deyatel'nosti na pervonachal'nom etape rassledovaniya prestupleniy [Some methodological problems of information and cognitive activity at the initial stage of the investigation of crimes]. Aktual'nyye problemy sledstvennoy deyatel'nosti / Otv. red. I.F. Gerasimov, L.YA. Drapkin. Sverdlovsk: Izd-vo Sverdl. yurid. ni-ta, s. 17-21. [in Russ.]

2. Belkin, R. S. (1997) Kurs kriminalistiki [Forensic science course]: v 3-kh t. M. : Norma, T. 3, 
393 s. [in Russ.]

3. Sledstvennyye deystviya (protsessual'naya kharakteristika, takticheskiye i psikhologicheskiye osobennosti) [Investigative actions (procedural characteristics, tactical and psychological characteristics)]: ucheb. posobiye dlya vuzov MVD SSSR. Volgograd : VSSH MVD SSSR, 1984. 155 s. [in Russ.]

4. Kryminalistyka [Forensics]: Pidruch. / Kol. avt.; za red. V. Yu. Shepit'ka. Kyyiv: Yurinkom Inter, 2001, 682 s. [in Ukr.]

5. Kriminalistika [Forensics]: Uchebnik / Pod red. A. N. Vasil'yeva. M. : Izd-vo MGU, 1980. 366 s. [in Russ.]

6. Chaplyns'kyy, K. O. (2006) Taktyka provedennya okremykh slidchykh diy [Tactics of conducting individual investigative actions]: Monohraf. Dnipropetrovs'k: Dniprop. derzh. un-t vnutr. sprav, 308 s. [in Ukr.]

7. Gavrilin, Yu. V., Golovin, A. Yu., Tishutina, I. V. (2006) Kriminalistika v ponyatiyakh i terminakh [Forensics in concepts and terms]: Ucheb. posobiye / Pod red. A. YU. Golovina. M.: Knizhnyy mir, 384 s. [in Russ.]

8. Yakimov, I. N. (1925) Kriminalistika : rukovodstvo po ugolovnoy tekhnike i taktike [Forensics: a guide to criminal technology and tactics]. M. : NKVD RSFSR, $430 \mathrm{~s}$. [in Russ.]

9. Ishchenko, Ye. P. (2007) Kriminalistika [Forensics]: Kurs lektsiy. M. : Yuridicheskaya firma «KONTRAKT»; AST-MOSKVA,. 416 s. [in Russ.]

10. Soroka, I. V. (2017) Rozsliduvannya kradizhok mayna hromadyan, vchynenykh nepovnolitnimy [Investigation of theft of citizens'property committed by minors]: dys. ... kandydata. yuryd. nauk : 12.00.09 / Dniprop. derzh. un. vnutr. Sprav. Dnipro, 256 s. [in Ukr.]

11. Stepanov, V. V. (2014) Sovremennyye problemy osmotra mesta proisshestviya [Modern problems of the inspection of the scene]. Sbornik materialov Mezhdunarodnoy nauchno-prakticheskoy konferentsii «Vliyaniye idey I. N. Yakimova na razvitiye sovremennoy kriminalistiki», posvyashchennoy 130letiyu so dnya rozhdeniya I. N. Yakimova. M., S. 86-91. [in Russ.]

12. Makarenko, Ye. I. (2009) Kradizhky z kvartyr: mystetstvo rozsliduvannya [Apartment Thefts: The Art of Investigation]: Monohraf. Dnipropetrovs'k: Dniprop. derzh. un-t vnutr. sprav, 150 s. [in Ukr.]

13. Soroka, I. V. (2013) Osoblyvosti provedennya slidchoho ohlyadu za faktamy vchynenykh nepovnolitnimy kradizhok mayna hromadyan [Peculiarities of conducting investigative inspection of the facts of juvenile theft of citizens' property]. Naukovyy visnyk Dnipropetrovs'koho derzhavnoho universytetu vnutrishnikh sprav. № 4. S. 444-449. [in Ukr.]

14. Kryminalistyka [Forensics]: pidruch. dlya stud. vyshch. navch. zakl. / K. O. Chaplyns'kyy, O. V. Luskatov, I. V. Pyrih, V. M. Pletenets', YU. A. Chaplyns'ka. Dnipro : Dniprop. derzh. un-t vnutr. sprav; Lira LTD, 2017. 419 s. [in Ukr.]

15. Polyvanyuk V. D. Taktychni osoblyvosti provedennya ohlyadu mistsya podiyi pry rozsliduvanni zlochyniv, vchynenykh $\mathrm{u}$ bankivs'kiy systemi Ukrayiny $\mathrm{z}$ vykorystannyam suchasnykh informatsiynykh tekhnolohiy [Tactical peculiarities of conducting an overview of the scene in the investigation of crimes committed in the banking system of Ukraine using modern information technologies]. Visnyk Zaporiz'koho natsional'noho universytetu. № 1. 2011. S. 243-248. [in Ukr.]

16. Antonyuk, Ye. V. (2016) Osobennosti provedeniya otdel'nykh sledstvennykh (rozysknykh) deystviy pri rassledovanii khuliganstva, predusmotrenogo ch. 4 st. 296 UK Ukrainy [Features of individual investigative (search) actions during the investigation of hooliganism, provided for in Part 4 of Art. 296 of the Criminal Code of Ukraine]. Mezhdunarodnyy nauchno-prakticheskiy zhurnal «Pravo $i$ Zakon». № 3. S. 53-58. [in Russ.]

17. Bystryts'kyy, B. Yu. (2015) Taktyka ohlyadu mistsya podiyi pid chas rozsliduvannya hrabezhiv, uchynenykh nepovnolitnimy [Tactics of inspection of a scene during investigation of robbery committed by minors]. Pravo i suspil'stvo, № 4, s. 166-170. [in Ukr.]

\section{Summary}

The scientific article deals with some aspects of investigating theft of luggage by citizens at the airport. The peculiarities of forensic support of the examination for faster investigation of the investigated category of criminal offenses are considered.

The author notes that the review is one of the most common investigative (search) actions in investigating theft of passenger luggage at airports. The obligatory identification and deletion of the specified information comes to the fore. After all, the traces of committing socially dangerous acts in places of large crowds can be lost fairly quickly.

We consider the following categories of persons to be involved in the inspection of the scene: employees of criminal police units (to protect the scene, to monitor the behavior of individuals, to inspect the surrounding area, to interview eyewitnesses, to conduct search operations); SRECC employee; the victims; patrol officers.

Keywords: theft, organization, tactics, investigative (search) actions, examination, forensic support. 